\title{
Rangeland Ecology \& Management, September 2016
}

\section{Carbon and Water Fluxes in an Exotic Buffelgrass Savanna}

César Hinojo-Hinojo, Alejandro E. Castellanos, Julio César Rodriguez, Josué Delgado-Balbuena, José R. Romo-León, Hernán Celaya-Michel, and Travis E. Huxman

Buffelgrass (Cenchrus ciliaris) savanna is widespread in arid lands due to invasion or land conversion for cattle grazing, but little is known about its carbon and water fluxes. Buffelgrass savanna within the Sonoran Desert was a carbon sink even in dry years; carbon fluxes were linked to evapotranspiration and influenced by rainfall pattern and species phenology. Degraded or burned buffelgrass savannas have lowered productivity and capacity to store carbon. Management should encourage healthy bufflegrass foliage to take advantage of summer monsoons and a diversity of native species to use water and store carbon during the rest of the year.

Importance of Early Season Conditions and Grazing on Carbon Dioxide Fluxes in Colorado Shortgrass Steppe

Jack A. Morgan, William Parton, Justin D. Derner, Tagir G. Gilmanov, and David P. Smith

We evaluated the influence of grazing intensity, soil water content (SWC), and plant cover (NDVI) on $\mathrm{CO}_{2}$ uptake in the Colorado shortgrass steppe. Early season SWC and NDVI were most highly correlated with $\mathrm{CO}_{2}$ uptake, while grazing intensity only had half the impact. Moderate grazing of the Colorado shortgrass steppe appears near-optimal for $\mathrm{CO}_{2}$ uptake under season-long continuous grazing, with annual climatic variability sometimes being more influential. To enhance $\mathrm{C}$ sequestration in the western Great Plains of North America, grazing management should emphasize flexible and adaptive practices that consider early-season
SWC and promote vegetation cover during the key early spring growth period.

\section{Understory Responses to Mechanical Treatment of Pinyon-Juniper in Northwest Colorado}

Garrett J. Stephens, Danielle Bilyeu Johnstone, Jayne L. Jonas, and Mark W. Paschke

Pinyon-juniper (PJ, Pinus spp. - Juniperus spp.) encroachment and declining mule deer (Odocoileus hemionus) populations in western Colorado have necessitated management for increased forage. To better understand PJ management techniques, we conducted an experiment to quantify understory responses to mechanical pinyon-juniper removal (anchor-chaining, rollerchopping, and mastication) and seed additions. All mechanical treatments greatly increased perennial understory abundance, but rollerchop produced the greatest amount of exotics; also, seeding was effective for increasing shrubs and native annuals. Results suggest any mechanical treatment can increase understory abundance to improve mule deer habitat and pre-treatment understory conditions are a good indicator of post-treatment outcomes.

\section{Mowing Wyoming Big Sagebrush (Artemisia tridentata ssp. wyomingensis) Cover Effects Across Northern and Central Nevada}

Sherman R. Swanson, John C. Swanson, Peter J. Murphy, J. Kent McAdoo, and Brad Schultz

Mowed fuel breaks in Wyoming big sagebrush (Artemisia tridentata wyomingensis) communities may increase resilience to disturbance. We compared cover at 76 adjacent mowed and unmowed Nevada areas. Mowing sagebrush before it is characterized by larger, well-spaced plants may strengthen the perennial herbaceous community, which should reduce the impact of fire. Conversely, mowing sagebrush in areas with 
widespread cheatgrass (Bromus tectorum) will likely increase cheatgrass and shift the community from woody and herbaceous to mostly herbaceous fuel comprised of flammable annuals. If cheatgrass is part of a pre-mowing community, supplemental treatment is necessary to prevent increase in cheatgrass after mowing.

Post-Fire Drill-Seeding of Great Basin Plants: Effects of Contrasting Drills on Seeded and Non-Seeded Species

Jeffrey E. Ott, Robert D. Cox, Nancy L. Shaw, Beth A. Newingham, Amy C. Ganguli, Mike Pellant, Bruce A. Roundy, and Dennis L. Eggett

Specialized seeding techniques may be required to restore Great Basin plant communities while minimizing the risks of erosion and weed invasion following wildfire. We planted native seed mixes using conventional and minimum-till drills constructed to place different-sized seeds in alternate rows. Establishment was generally better with the minimum-till drill for small-seeded species and the conventional drill for large-seeded species. Soil disturbance associated with the conventional drill reduced exotic annuals during the first year, but also had a negative effect on residual perennials. These drills have different advantages, but either can be effective if configured properly, provided conditions are otherwise favorable for seedling establishment.

\section{Use of a UAV-Mounted Video Camera to Assess Feeding Behavior of Raramuri Criollo Cows}

Shelemia Nyamuryekung'e, Andrés F. Cibils, Richard E. Estell, and Alfredo L. Gonzalez

Unmanned aerial vehicles or drones are being used increasingly to monitor rangeland vegetation and wildlife populations. We conducted a series of controlled tests to determine whether an off-the-shelf multi-copter could be used to predict intake of discrete food items by Mexican Criollo cows. The presence of a drone hovering 82 feet above the cows during 12-minute tests did not appear to alter their behavior. Feeding frequency estimates derived from video footage captured by the drone was significantly correlated with feed intake of individual cows. Drone video monitoring could be a useful tool to assess feeding behavior of cows on rangelands.

Forage Kochia and Russian Wildrye Potential for Rehabilitating Gardner's Saltbush Ecosystems Degraded by Halogeton

Rob C. Smith, Blair L. Waldron, J. Earl Creech, R. Aaron Zobell, and Dale R. ZoBell

Salt desert shrub ecosystems are increasingly being invaded by the annual weed halogeton (Halogeton glomeratus). This study compared the relative abilities of forage kochia (Bassia prostrata), Russian wildrye (Psathyrostachys juncea), tall wheatgrass (Thinopyrum ponticum), Indian ricegrass (Achnatherum hymenoides), and Gardner's saltbush (Atriplex garneri) to establish, persist, and subsequently reduce halogeton establishment in a Gardner's saltbush ecosystem. Forage kochia and Russian wildrye established, persisted, and reduced halogeton frequency; whereas, Gardner's saltbush, tall wheatgrass, and Indian ricegrass either did not establish or persist. These results indicate that Russian wildrye and forage kochia can provide an opportunity for rehabilitation of halogeton-invaded areas.

The Role of Herbivore Impact and Subsequent Timing and Extent of Recovery Periods in Rangelands

\section{Edwin I. Mudongo, Richard W.S. Fynn, and Mpaphi C. Bonyongo}

The response of grassland vegetation to grazing history remains the subject of debate to rangeland managers and researchers. We investigated the effect of simulated herbivory in the previous growing season, and length and timing of recovery periods on grassland functional responses in the Botswana Kalahari. We found that optimal grassland productivity is achieved by a full growing season recovery period and nonselective defoliation that disadvantages the less grazing tolerant unpalatable species. Our results have important implications on the timing and length of grazing, recovery periods, and the spatial distribution of grazing on semi-arid, nutrient poor rangelands.

\section{Does Supplemental Feeding of White-Tailed Deer Alter Response of Palatable Shrubs to Browsing?}

Whitney Gann, Timothy Fulbright, Eric Grahmann, David Hewitt, Charles DeYoung, David Wester, Blaise Korzekwa, Kim Echols, and Don Draeger

The impact on palatable shrubs when herbivores have access to high-quality food is debated and unclear, especially in the southwestern range of white-tailed deer (Odocoileus virginintus). We determined if providing high quality food and increasing deer density reduced growth and altered nutritional quality of the palatable shrubs Texas kidneywood (Eysenhardtia texana) and spiny hackberry (Celtis ebrenbergiana). Access to feed did not alter the effects of browsing on these shrubs. However, increased deer density reduced growth of Texas kidneywood, while spiny hackberry produced compensatory growth. We found no evidence that access to high-quality food results in widespread habitat degradation. 
Tragelaphus Strepsiceros Browse During the Wet Season in the Mopani Veld of Limpopo Province, South Africa

Rudzani A. Makhado, Martin J. Potgieter, Wilmien J. Luus-Powell, Susan M. Cooper, and Grzegorz Kopij

Greater kudu management (Tragelaphus strepsiceros) in southern Africa's mopani woodland is constrained by limited information on their diet, particularly during the wet season. Based on rumen samples, Combretum apiculatum comprised most of the wet season diet (43\%). Other plants browsed were Sclerocarya birrea (24\%), Colophospermum mopane (12\%), and Acacia nigrescens (8\%). Leaves were the plant parts browsed most often (81\%); the remaining 19\% of the diet consisted mainly of Sclerocarya birrea fruit. Females appeared to use a wider variety of species than males. Management of mopani woodland needs to consider these browse species for conservation of the greater kudu in mopani veld.

Rangelands (38)5:307-309

doi: $10.1016 /$ j.rala.2016.08.003 